\title{
Correlation between Electrochemical and Theoretical Studies on the Leishmanicidal Activity of Twelve Morita-Baylis-Hillman Adducts
}

\author{
Yen G. de Paiva, ${ }^{a, b}$ Antônio A. de Souza, ${ }^{b, c}$ Claudio G. Lima-Junior, ${ }^{a}$ Fábio P. L. Silva, ${ }^{a}$ \\ Edilson B. A. Filho, ${ }^{a, d}$ Camila C. de Vasconcelos, ${ }^{b}$ Fabiane C. de Abreu, ${ }^{b}$ \\ Marília O. F. Goulart ${ }^{*, b}$ and Mário L. A. A. Vasconcellos $*, a$
}

\begin{abstract}
${ }^{a}$ Departamento de Química, Universidade Federal da Paraíba, Campus I, 58059-900 João Pessoa-PB, Brazil
${ }^{b}$ Instituto de Química e Biotecnologia, Universidade Federal de Alagoas, 57072-970 Maceió-AL, Brazil
\end{abstract}

cDepartamento de Química, Instituto Federal de Alagoas, 57020-600 Maceió-AL, Brazil

${ }^{d}$ Colegiado de Ciências Farmacêuticas, Universidade Federal do Vale do São Francisco, 56304-917 Petrolina-PE, Brazil

O processo de biorredução enzimática do grupo nitro é de grande importância para a ação molecular de nitrocompostos aromáticos biologicamente ativos. Os métodos eletroquímicos são considerados ferramentas úteis para a simulação de processos metabólicos in vivo. No presente trabalho, realizaram-se estudos eletroquímicos em meio aprótico $(N, N$-dimetilformamida (DMF) mais perclorato de tetrabutilamônio (TBAP) $0,1 \mathrm{~mol} \mathrm{~L}^{-1}$ ) utilizando-se as técnicas de voltametria cíclica (CV), de pulso diferencial (DPV) e de onda quadrada (SWV) de 12 adutos de Morita-Baylis-Hillman (MBHA) com atividade leishmanicida significativa. Para facilitar a análise, os adutos foram agrupados em quatro classes de acordo com a cadeia lateral. Os estudos de CV evidenciam duas ondas referentes à redução do grupo nitro e uma ou duas outras ondas (em potencial mais negativo) relativas à redução da função carbonila $\alpha, \beta$-insaturada ou da olefina ativada por grupos nitrila. Adutos orto-substituídos apresentam maior facilidade de redução quando comparados aos demais isômeros (meta e para) em função, provavelmente, da ligação de hidrogênio entre o grupo nitro e a hidroxila benzílica, o que estabiliza mais o produto eletrogerado do que o composto de partida. Derivados orto também mostram uma maior atividade leishmanicida em comparação com seus isômeros em cada série. Estudos conformacionais usando HF/6-31+G(d)/PCM como nível de cálculo evidenciaram este efeito. Valores calculados de dureza molecular $(N)$ e de cargas atômicas $\left(\mathrm{Q}_{\mathrm{N}}\right)$ explicam corretamente os dados experimentais obtidos.

Enzymatic bioreduction of nitro groups plays an important role on the activity of biologically active nitroaromatic compounds. Electrochemical methods are useful tools to simulate in vivo metabolic processes. This work presents electrochemical studies in aprotic media ( $N, N$-dimethylformamide (DMF) plus tetrabutylammonium perchlorate (TBAP) $0.1 \mathrm{~mol} \mathrm{~L}^{-1}$ ) using cyclic voltammetry (CV), differential pulse voltammetry (DPV) and square wave voltammetry (SWV) of twelve Morita-Baylis-Hillman adducts (MBHA) with significant leishmanicidal activity. To facilitate the analysis, the molecules were grouped in four classes according to the side chain. $\mathrm{CV}$ studies show three up to four reduction waves, in which the first two waves are related to nitro group reduction. The other waves (presenting more negative potential) refer to the reduction of the $\alpha, \beta$-unsaturated carbonyl or to the nitrile activated olefin side-chain. Ortho adducts present facilitated reduction in comparison to the other isomers (meta and para) possibly due to hydrogen bond formation between the benzylic- $\mathrm{OH}$ and the nitro group, which stabilizes the reduction product (anion radical nitro) more efficiently than the original compound. Ortho derivatives also present higher leishmanicidal activity upon comparison to the other derivatives of each class. Conformational studies using $\mathrm{HF} / 6-31+\mathrm{G}(\mathrm{d}) / \mathrm{PCM}$ as a calculation level highlight this effect. Molecular hardness $(N)$ and atomic charges $\left(\mathrm{Q}_{\mathrm{N}}\right)$ values corroborate the obtained experimental data.

Keywords: Morita-Baylis-Hillman adducts, electrochemical parameters, nitrocompounds, biological activity, computational studies, Leishmania

*e-mail: mofg@qui.ufal.br, mlaav@quimica.ufpb.br 


\section{Introduction}

The Morita-Baylis-Hillman reaction (MBHR) is an important green atom-economical carbon-carbon bond-forming reaction, ${ }^{1}$ generating polyfuncionalized molecules with large biological activity spectra. ${ }^{2}$ It involves coupling of alkenes containing electron-withdrawing groups (EWG) with aldehydes, imines or ketones, among other starting materials. Most of these reactions are usually catalyzed by tertiary amines such as 1,4-diazabicyclo[2.2.2] octane (DABCO) (Scheme 1). Several Morita-Baylis-Hillman adducts (MBHA) present functional groups, such as nitro in their structure, which are capable of interacting with biomolecules. Kundu et al. ${ }^{3}$ reported for the first time the antimalarial activity of these compounds. The effects of MBHA on biological targets were also investigated, showing significant activity against the snail Biomphalaria glabrata (secondary vector of schistosomiasis), ${ }^{4}$ and parasites that cause Malaria, Leishmaniasis and Chagas disease. ${ }^{5}$ Moreover, they also work as bactericidal, ${ }^{6}$ fungicidal $^{7}$ and antitumor compounds against some human cancer cells. ${ }^{8}$

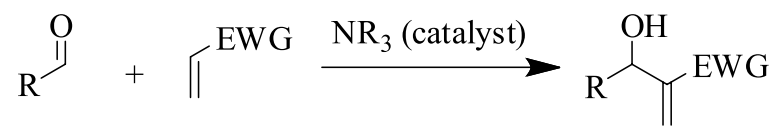

MBHA

$\mathrm{R}=$ alkyl, aryl, $\mathrm{H}$

$\mathrm{EWG}=\mathrm{CO}_{2} \mathrm{R}, \mathrm{CN}, \mathrm{COR}$, others

Scheme 1. General scheme for Morita-Baylis-Hillman reactions.

The biological activity of nitrocompounds is associated to nitro group reduction that generates $\mathrm{RNO}_{2}^{-}$or more reduced intermediates. ${ }^{9}$ The process of nitro group enzymatic bioreduction is important for the biological activity of nitroaromatic compounds. Considering biotransformation, nitro group can undergo several reactions and lead to toxic metabolites, i.e., nitro radical anion and/or hydroxylamine and/or nitroso derivatives. In vivo, reductive metabolism is carried out by flavinesdependent reductases, which are able to use these compounds as electron acceptors. Redox potentials are considered the main physicochemical parameter to determine the effectiveness of nitrocompounds, providing thermodynamic and kinetic information about electron transfer (ET) process. ${ }^{9,10}$ Mimicking cell conditions, hydrophilic (protic media) or lypophilic (aprotic media) environments are crucial to understand the facilitation of the reduction process (represented by Epc ${ }_{1}$ ), the biological activity and the mechanism of action against several parasites, including Trypanosoma cruzi ${ }^{11}$ and Leishmania. ${ }^{12}$
Leishmaniasis is a vector-borne disease caused by different protozoan species of the genus Leishmania, an obligate intramacrophage parasite. This neglected disease is currently one of the most important health problems in several developing countries, with approximately 350 million people at risk. The current available treatment is unsatisfactory due to high cost, toxic side effects and drug resistance developed by the parasites. ${ }^{13}$

In our continuing efforts towards the synthesis, bioevaluation against parasites that cause Leishmaniasis and Chagas disease, ${ }^{5}$ and conformational studies of Morita-Baylis-Hillman adducts (MBHA), ${ }^{14}$ the present work aimed to investigate the electrochemical behavior of twelve MBHA in aprotic media $(N, N$-dimethylformamide (DMF) plus tetrabutylammonium perchlorate (TBAP) $0.1 \mathrm{~mol} \mathrm{~L}^{-1}$ ), as well as theoretical aspects of these compounds. The correlation between the theoretical and electrochemical information obtained here with biological activity against Leishmania amazonensis, previously observed, was analyzed.

\section{Experimental}

\section{Chemicals}

MBHA were synthesized following previously published procedures. ${ }^{15}$ Spectroscopic and spectrometric data of MBHA Ia-IVc are available in the Supplementary Information (SI) section. It is noteworthy that the spectra of IIIa, IIIb, IIIc, IVa, IVa, VIb and IVc, also available in the SI section, were included for the first time.

\section{Equipment and procedure}

All experiments were conducted at room temperature $\left(25 \pm 2{ }^{\circ} \mathrm{C}\right)$ and degassing was performed by purging an inert gas (Argon). Cyclic voltammetry (CV), differential pulse voltammetry (DPV) and square wave voltammetry (SWV) were performed with a conventional three-electrode cell (with volumetric capacity of $10 \mathrm{~mL}$ ) in an Autolab PGSTAT-30 potentiostat (Echo Chemie, Utrecht, the Netherlands) coupled to a microcomputer, using GPES 4.9 software. The working electrode was a Metrohm GC electrode of $3 \mathrm{~mm}$ diameter, the counter electrode was a platinum coil and the reference electrode was $\mathrm{Ag} \mid \mathrm{AgCl}, \mathrm{Cl}^{-}$ $\left(0.1 \mathrm{~mol} \mathrm{~L}^{-1}\right)$. The glassy carbon electrode was previously polished with alumina on a polishing felt until a mirrorlike surface appearance was obtained. The solvent used in aprotic media studies was distilled under reduced pressure after stirring with anhydrous copper sulfate. For DPV measurements, the pulse amplitude was $50 \mathrm{mV}$, the step 
potential was $10 \mathrm{mV}$, and the scan rate was $10 \mathrm{mV} \mathrm{s}^{-1}$. In CV experiments, the scan rate varied from 35 to $1000 \mathrm{mV} \mathrm{s}^{-1}$. Argon was used to degas the solution, which was covered with an Argon blanket during the experiments.

\section{Computational details}

Computational analyses were performed using GAUSSIAN09W ${ }^{\circledR}$ package version for Linux. ${ }^{16}$ Initially, relaxed potential energy surfaces scan (RPESS) was performed in a semi-empirical AM1 level, considering the relevant rotational degrees of freedom for MBHAs (sigma bonds). Dihedral angles were frozen in steps of $10^{\circ}$, while the remaining portion of the molecule was optimized. At the end, potential energy curves for each dihedral angle were obtained, were the conformation of minimum energy was selected. They were, then, subjected to calculation at HF/6-31G+(d) level, considering a polarized continuum model (PCM) by introducing DMF dielectric constant $(\varepsilon=37.50)$.

The HOMO (highest occupied molecular orbital) and LUMO (lowest unoccupied molecular orbital) and the Mulliken charge (of $-\mathrm{NO}_{2}$ nitrogen atom) values were obtained from the most stable conformations of MBHA. The molecular hardness $(N)$ was calculated from $\mathrm{N}=[(\mathrm{LUMO}+\mathrm{HOMO}) / 2]$ equation. ${ }^{17}$

\section{Results and Discussion}

The syntheses of the studied compounds (Figure 1), as well as their physicochemical data, have been previously reported. ${ }^{15}$ Purity of all compounds was assessed by gas chromatography (SI section). Classes I, II, III and IV were classified as nitrile, methyl acrylate, 2-hydroxyethylacrylate and propyl acrylate, based on the side chain. Letters a, b and c refer to ortho, meta and para substitution of the side chain on the aromatic ring.

\section{Electrochemical studies: aprotic media}

The cyclic voltammetry of nitro derivatives in all series (on a glassy carbon electrode) in DMF + TBAP $0.1 \mathrm{~mol} \mathrm{~L}^{-1}$ are shown in Figures 2, 3, 4 and 5. In this medium, three to four reduction waves were observed. The first two waves were related to the nitroaromatic function, and the third (and fourth) to the acrylate moiety (Figure 6). ${ }^{9}$

The generation of stable nitro-anion radical was observed (system Ic/Ia) (Figures 2, 3, 4 and 5: b, d, f, Figure 6, equation 1) in a diffusion-controlled reversible system $\left(\mathrm{Epc}_{1}\right.$ independent of scan rate and $\mathrm{Ip}_{\mathrm{a}} / \mathrm{Ip}_{\mathrm{c}} c a .1$ ), followed by a second wave related to generation of hydroxylamine (Figure 6, equation 2) that would suffer oxidation at Epa2, except for the ortho derivative. There was no corresponding response in the second successive scan related to the reversible 2-electron RNO/RNHOH couple, suggesting an instability of hydroxylamine in this medium ${ }^{10,18}$ (data not shown). Table 1 lists the main electrochemical parameters $\left(\mathrm{Epc}_{1}\right)$ for the studied compounds.

These compounds were also studied by SWV (Figure 7) and DPV (Figure 8). DPV showed three reduction waves, except for Ia adduct. Nitro radical anion wave was characterized as a well-defined and intense current peak. The other waves were related to olefin system reduction (Figure 8). SWV forward and backward currents for the second scan clearly showed the reversibility of the electrogenerated nitro anion radical system and the irreversibility of the following waves. Table 2 lists the main obtained values.

One or two additional irreversible cathodic waves $\left(\mathrm{Epc}_{3}\right.$ and $\left.\mathrm{Epc}_{4}\right)$ were related to $\alpha, \beta$-unsaturated ester or nitrile activated olefin reduction. Souza and co-workers ${ }^{9}$ were the first to perform electrochemical investigations of MBHA. According to these authors, compound IIc $\left(1 \mathrm{mmol} \mathrm{L}^{-1}\right)$ shows an irreversible cathodic wave $\left(\right.$ Epc $=-2.24 \mathrm{~V}$ at $\left.100 \mathrm{mV} \mathrm{s}{ }^{-1} ; \mathrm{Ep}-\mathrm{Ep}_{1 / 2}=152 \mathrm{mV}\right){ }^{9}$ Thus, the similarities between MBHA reduction potential observed here and the study by Souza and co-workers ${ }^{9}$ suggest that the additional cathodic waves may be related to the $\alpha, \beta$-unsaturated ester or nitrile-conjugated double bond. Corroborating this, the electrochemical studies performed with methyl 2-phenylhydroxymethyl acrylate revealed this profile (Figure 9).

In general, the isolated double bonds are not reducible under electrochemical conditions, however, electron<smiles>[R]C(=C)C(O)c1ccccc1[N+](=O)[O-]</smiles>

Ia: $\mathrm{R}=\mathrm{CN}$

IIa: $\mathrm{R}=\mathrm{CO}_{2} \mathrm{CH}_{3}$

IIIa: $\mathrm{R}=\mathrm{CO}_{2} \mathrm{CH}_{2} \mathrm{CH}_{2} \mathrm{OH}$

IVa: $\mathrm{R}=\mathrm{CO}_{2} \mathrm{CH}_{2} \mathrm{CH}_{2} \mathrm{CH}_{3}$<smiles>[R]C(=C)C(O)c1cccc([N+](=O)[O-])c1</smiles>

Ib: $\mathrm{R}=\mathrm{CN}$

IIb: $\mathrm{R}=\mathrm{CO}_{2} \mathrm{CH}_{3}$

IIIb: $\mathrm{R}=\mathrm{CO}_{2} \mathrm{CH}_{2} \mathrm{CH}_{2} \mathrm{OH}$

$\mathrm{IVb}: \mathrm{R}=\mathrm{CO}_{2} \mathrm{CH}_{2} \mathrm{CH}_{2} \mathrm{CH}_{3}$

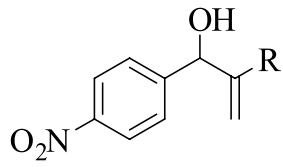

Ic: $\mathrm{R}=\mathrm{CN}$

IIc: $\mathrm{R}=\mathrm{CO}_{2} \mathrm{CH}_{3}$

IIIc: $\mathrm{R}=\mathrm{CO}_{2} \mathrm{CH}_{2} \mathrm{CH}_{2} \mathrm{OH}$

IVc: $\mathrm{R}=\mathrm{CO}_{2} \mathrm{CH}_{2} \mathrm{CH}_{2} \mathrm{CH}_{3}$

Figure 1. Chemical structures of the studied MBHA. 

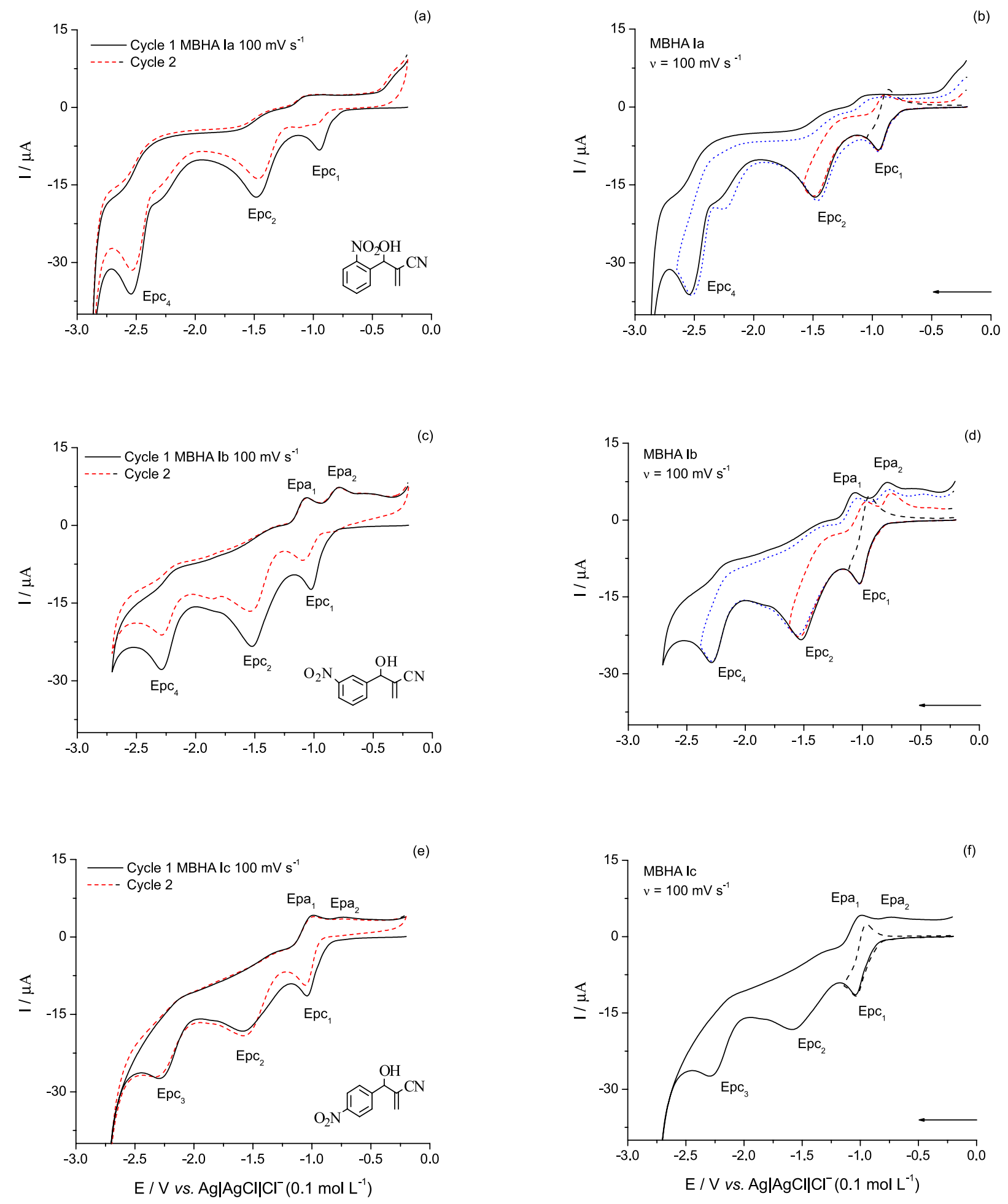

Figure 2. Cyclic voltammograms of MBHA class $\mathrm{I}\left(1 \mathrm{mmol} \mathrm{L}^{-1}\right)$ in aprotic media (DMF + TBAP $\left.0.1 \mathrm{~mol} \mathrm{~L}^{-1}\right), v=100 \mathrm{mV} \mathrm{s}^{-1}$. Working electrode: GCE Metrohm (3 mm diameter); counter electrode: platinum coil; reference electrode: $\mathrm{Ag} \mid \mathrm{AgCl}, \mathrm{Cl}^{-}\left(0.1 \mathrm{~mol} \mathrm{~L}^{-1}\right)$.

capture is facilitated when olefins are electron-poor, for instance, when they are conjugated to an electron withdrawing $\pi$-system such as carboalkoxyl or nitrile groups. $\alpha, \beta$-Unsaturated esters have a complex electrochemical behavior profile, nevertheless, saturation of the double bound is the most common event, thus, Epc $_{3}$ can be related to the formation of the methyl derivative side-chain. ${ }^{19}$

Some substituents may affect the electron distribution of several chemicals, changing their reduction potentials and influencing the stability of electrogenerated species. ${ }^{20} \mathrm{In}$ 

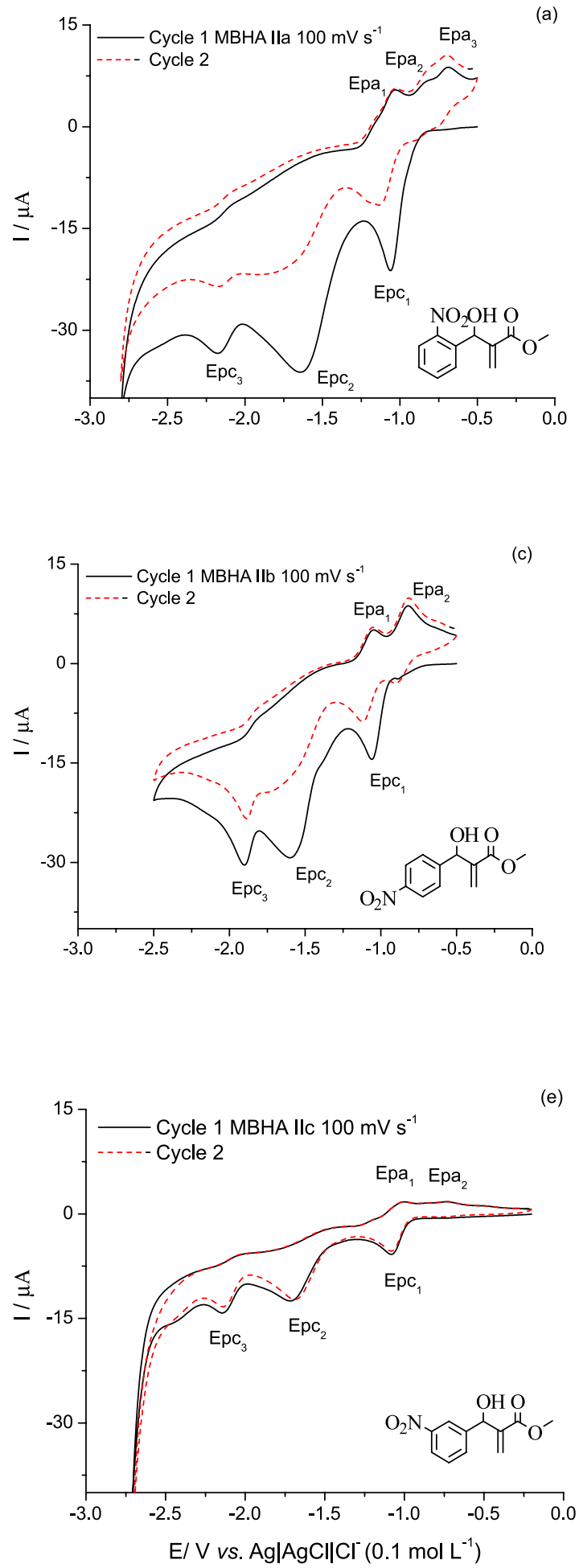
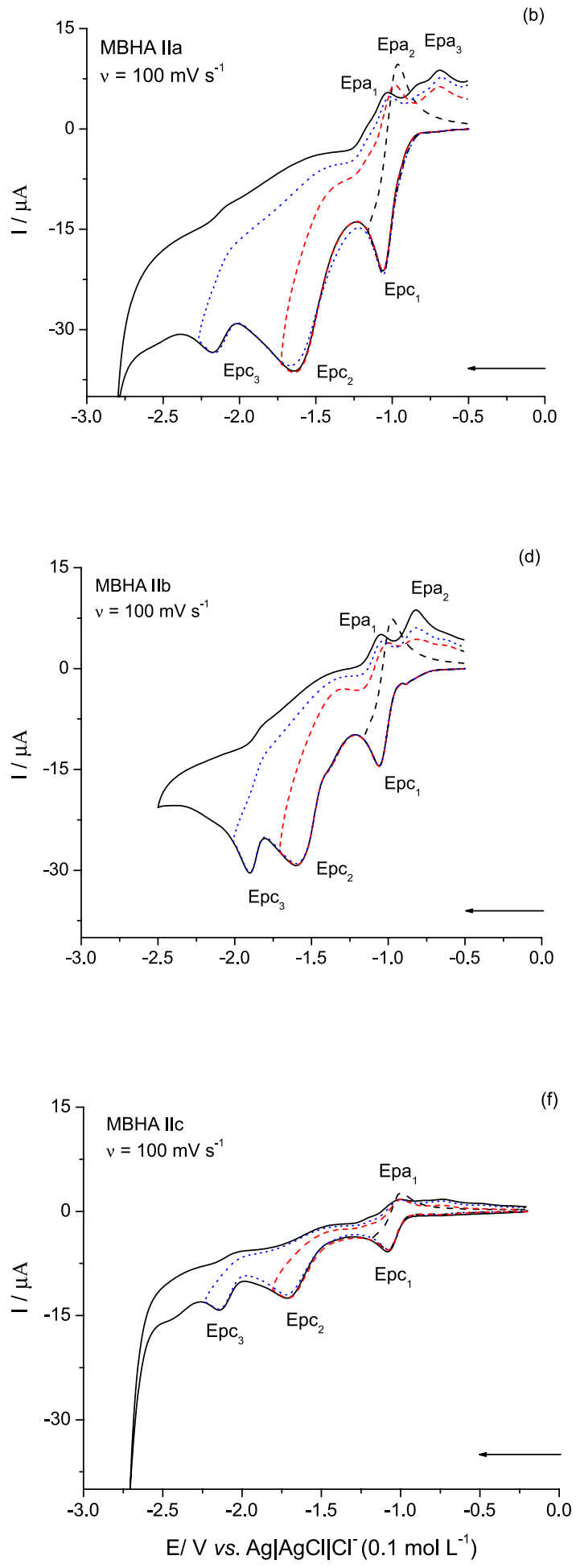

Figure 3. Cyclic voltammograms of MBHA class II $\left(1 \mathrm{mmol} \mathrm{L}{ }^{-1}\right)$ in aprotic media (DMF + TBAP $\left.0.1 \mathrm{~mol} \mathrm{~L}^{-1}\right), v=100 \mathrm{mV} \mathrm{s}^{-1}$. Working electrode: GCE (Metrohm, 3 mm diameter); counter electrode: platinum coil; reference electrode: $\mathrm{Ag} \mid \mathrm{AgCl}, \mathrm{Cl}^{-}\left(0.1 \mathrm{~mol} \mathrm{~L}^{-1}\right)$.

qualitative terms, electron-donating groups turn the reduction process more difficult, whereas electron withdrawing groups facilitate it. ${ }^{10,11,20}$ The ortho-substituent must be carefully analyzed due to effects other than the usual interactions such as hydrogen bonding and field effects. ${ }^{10}$
The reduction of nitrocompounds as well as formation and stabilization of electrogenerated species are environment-dependent molecular processes. ${ }^{10}$

The ortho-substituted MBHA (a) exhibited easier reduction followed by its isomers meta (b) and para (c). 

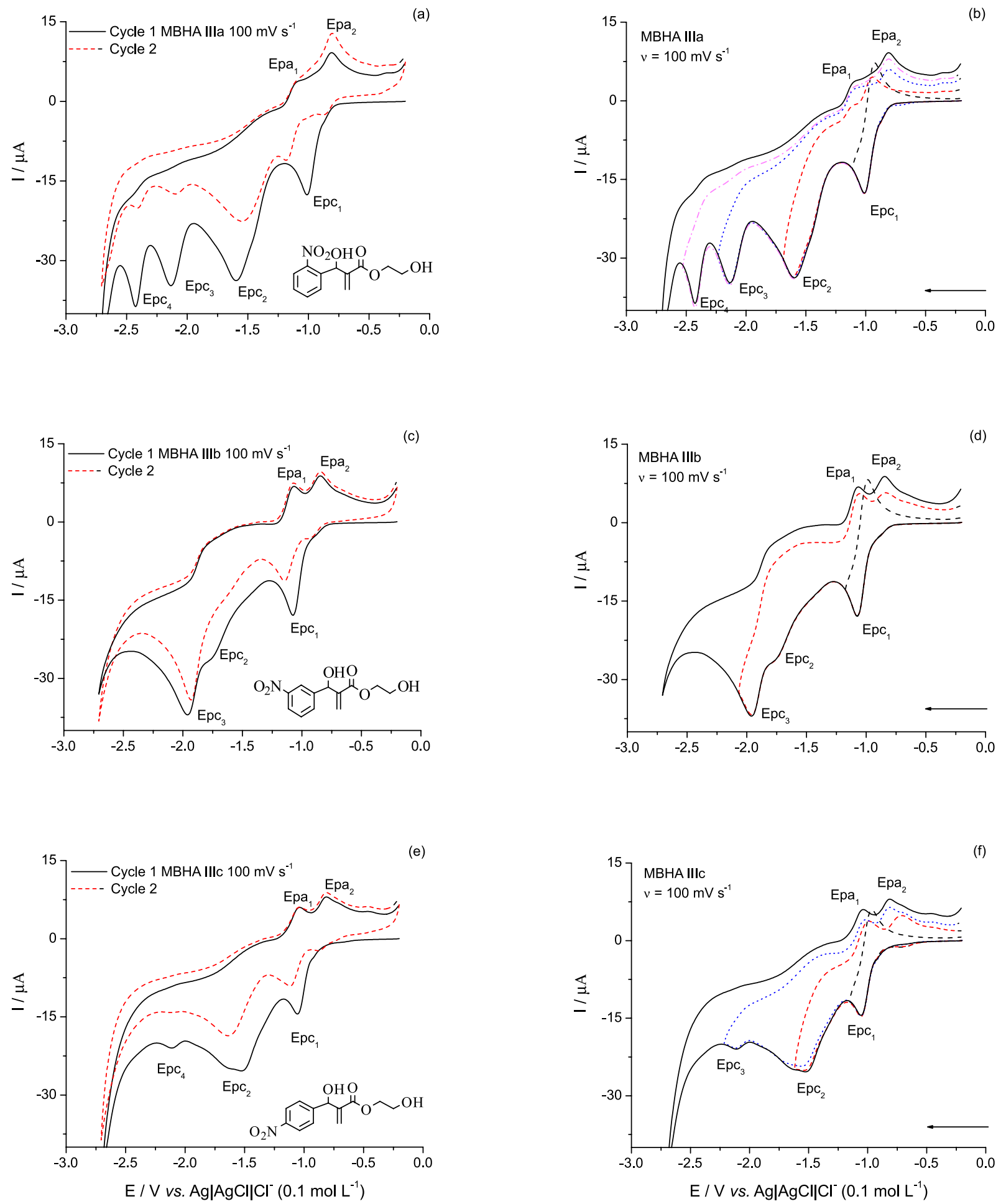

Figure 4. Cyclic voltammograms of MBHA class III $\left(1 \mathrm{mmol} \mathrm{L}^{-1}\right)$ in aprotic media (DMF + TBAP $\left.0.1 \mathrm{~mol} \mathrm{~L}^{-1}\right), v=100 \mathrm{mV} \mathrm{s}^{-1}$. Working electrode: GCE (Metrohm, $3 \mathrm{~mm}$ diameter); counter electrode: platinum coil; reference electrode: $\mathrm{Ag} \mid \mathrm{AgCl}, \mathrm{Cl}^{-}\left(0.1 \mathrm{~mol} \mathrm{~L}^{-1}\right)$.

The order of nitro reduction facilitation in each class (represented by $\left.\mathrm{Epc}_{1}\right)$ (Table 1) is:

Ia $>$ Ib $>$ Ic; IIa $>$ IIb $>$ IIc; IIIa $>$ IIIb $>$ IIIc and IVa $>$ $\mathrm{IVb}>\mathrm{IVc}$
The observed differences in reduction potentials may be due to hydrogen bond formation between the benzylic-OH and the nitro group, giving a 7-membered ring, which stabilizes the reduction product (nitro anion radical) more than the original compound. In regards to the 

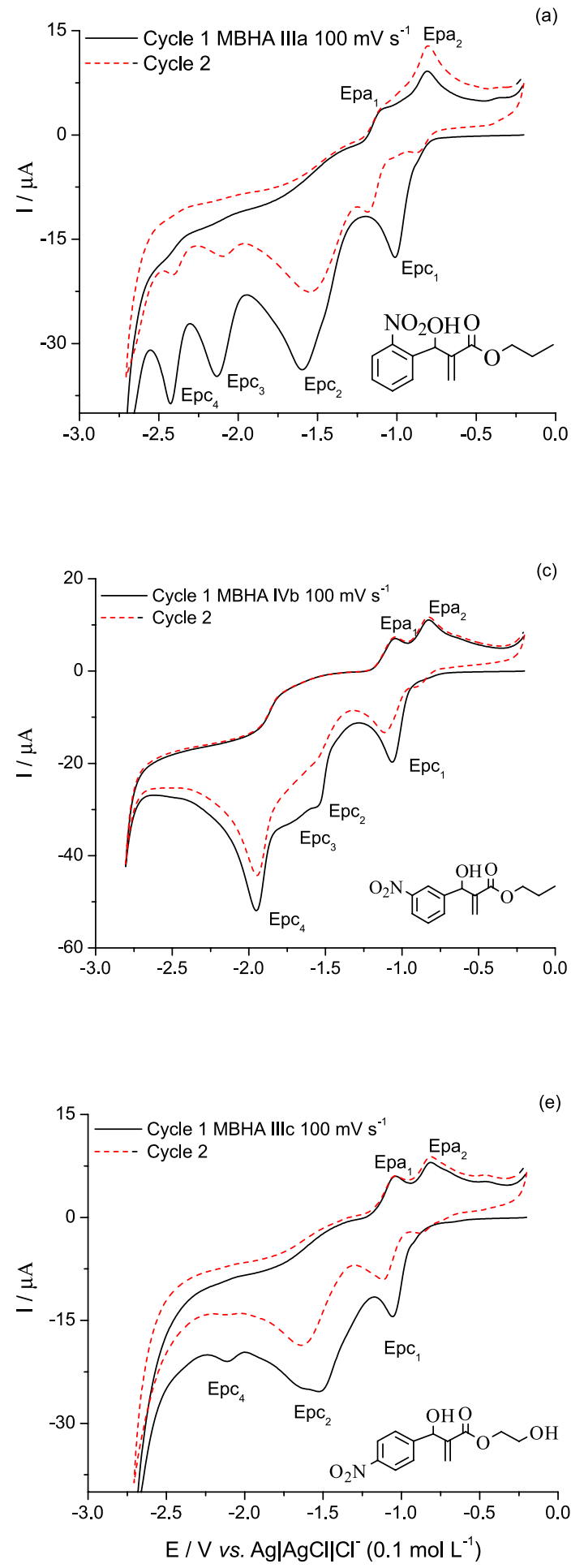
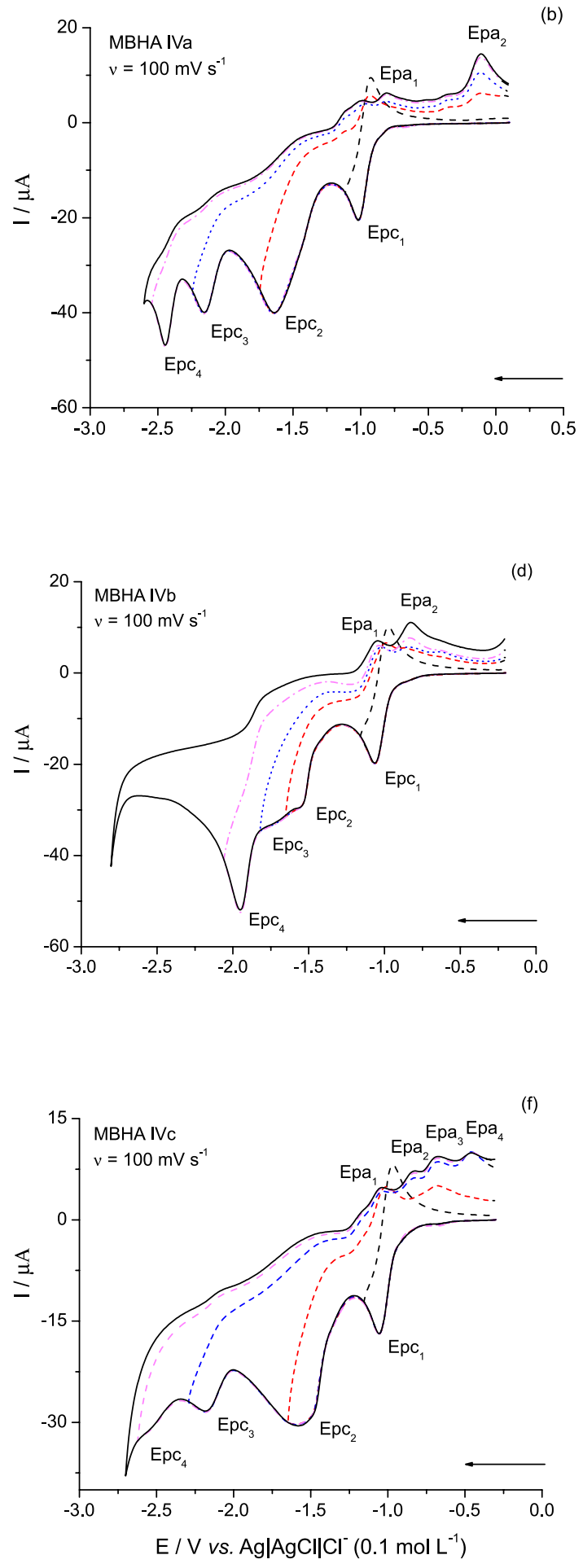

Figure 5. Cyclic voltammograms of MBHA class IV $\left(1 \mathrm{mmol} \mathrm{L}^{-1}\right)$ in aprotic media (DMF + TBAP $\left.0.1 \mathrm{~mol} \mathrm{~L}^{-1}\right), v=100 \mathrm{mV} \mathrm{s}^{-1}$. Working electrode: GCE (Metrohm, $3 \mathrm{~mm}$ diameter), counter electrode: platinum coil; reference electrode: $\mathrm{Ag} \mid \mathrm{AgCl}, \mathrm{Cl}^{-}\left(0.1 \mathrm{~mol} \mathrm{~L}^{-1}\right)$.

side chain, MBHA with the nitrile group (class I) showed higher reduction potential (facilitated reduction) compared to the ester derivatives (Tables 1 and 2):

Ia $>$ IIII $c a$ IVa $>\mathrm{IIa} ; \mathrm{Ib}>\mathrm{IIIb} c a . \mathrm{IVb}>\mathrm{IIb} ; \mathrm{Ic}>\mathrm{IIII} c a . \mathrm{IV} c>\mathrm{IIc}$
Despite the slight difference in potential values (Table 1), it is noteworthy the higher reduction values of Ia and IVa.

As reduction generates more polar compounds, some effects are much stronger in these species than in starting 
<smiles>C=C(C#N)C(O)c1cccc([N+](=O)[O-])c1</smiles><smiles></smiles><smiles>C=C(C#N)C(O)c1cccc([N+](=O)[O-])c1</smiles><smiles>C=C(Cl)C(O)c1cccc([N+](=O)[O-])c1</smiles><smiles>[13CH2][13CH2][13CH2]</smiles><smiles>C=C(C#N)C(O)c1cccc(NO)c1</smiles>

Figure 6. Scheme for reduction of adduct $\mathrm{Ib}$ in aprotic medium DMF + TBAP $0.1 \mathrm{~mol} \mathrm{~L}^{-1}$ (also applied to other members of this class).

Table 1. Reduction potentials of MBHA classes I, II, III and IV in aprotic media DMF + TBAP $0.1 \mathrm{~mol} \mathrm{~L}^{-1}, v=100 \mathrm{mV} \mathrm{s}^{-1}$. Working electrode: glassy carbon electrode (GCE) (Metrohm $3 \mathrm{~mm}$ ); auxiliary electrode: platinum wire; reference electrode: $\mathrm{Ag} \mid \mathrm{AgCl}, \mathrm{Cl}^{-}$

\begin{tabular}{|c|c|c|c|c|c|c|c|c|c|}
\hline MBHA & $\mathrm{Epc}_{1} / \mathrm{V}$ & $\mathrm{Epc}_{2} / \mathrm{V}$ & $\mathrm{Epc}_{3} / \mathrm{V}$ & $\mathrm{Epc}_{4} / \mathrm{V}$ & $\mathrm{AMBH}$ & $\mathrm{Epc}_{1} / \mathrm{V}$ & $\mathrm{Epc}_{2} / \mathrm{V}$ & $\mathrm{Epc}_{3} / \mathrm{V}$ & $\mathrm{Epc}_{4} / \mathrm{V}$ \\
\hline Ia & -0.944 & -1.470 & a & -2.537 & IIIa & -1.014 & -1.597 & -2.137 & -2.425 \\
\hline $\mathrm{Ib}$ & -1.028 & -1.520 & a & -2.291 & IIIb & -1.077 & -1.751 & -1.962 & a \\
\hline Ic & -1.029 & -1.429 & a & a & IIIc & -1.056 & -1.527 & a & -2.116 \\
\hline IIa & -1.061 & -1.644 & -2.178 & a & IVa & -1.009 & -1.634 & -2.153 & -2.441 \\
\hline $\mathrm{IIb}$ & -1.062 & -1.602 & -1.904 & a & $\mathrm{IVb}$ & -1.063 & -1.541 & -1.702 & -1.948 \\
\hline IIc & -1.084 & -1.716 & -2.144 & a & IVc & -1.058 & -1.648 & -2.188 & a \\
\hline
\end{tabular}

${ }^{a}$ not present.

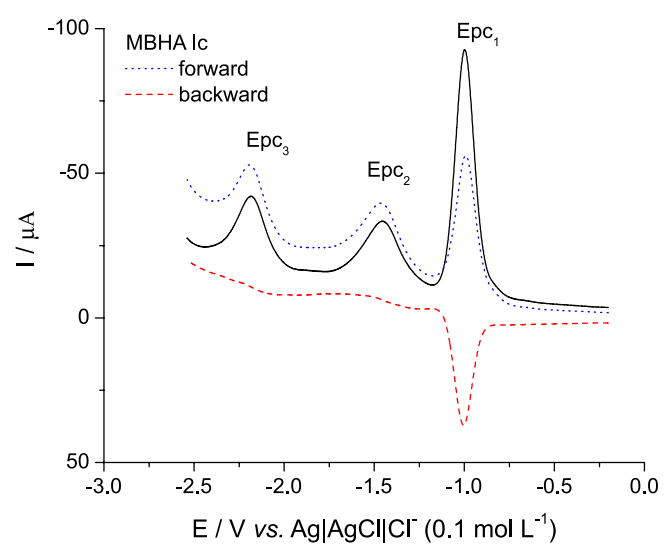

Figure 7. Square wave voltammogram MBHA class $I\left(1 \mathrm{mmol} \mathrm{L}^{-1}\right)$ in aprotic media (DMF + TBAP $\left.0.1 \mathrm{~mol} \mathrm{~L}^{-1}\right), v=100 \mathrm{mV} \mathrm{s}^{-1}$. Working electrode: GCE (Metrohm, $3 \mathrm{~mm}$ diameter); counter electrode: platinum coil; reference electrode: $\mathrm{Ag} \mid \mathrm{AgCl}, \mathrm{Cl}^{-}\left(0.1 \mathrm{~mol} \mathrm{~L}^{-1}\right)$.

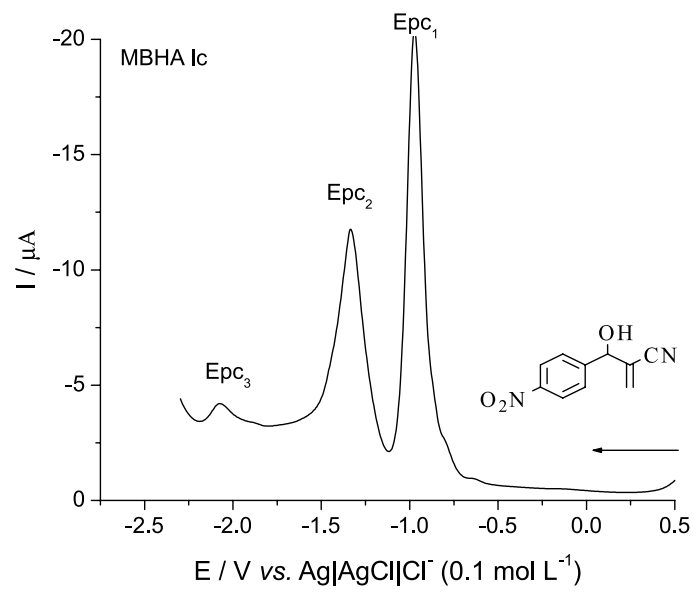

Figure 8. Differential pulse voltammogram of MBHA class $\mathrm{I}\left(1 \mathrm{mmol} \mathrm{\textrm {L } ^ { - 1 } )}\right.$ in aprotic media (DMF + TBAP $\left.0.1 \mathrm{~mol} \mathrm{~L}^{-1}\right)$. Working electrode: GCE (Metrohm, $3 \mathrm{~mm}$ diameter); counter electrode: platinum coil; reference electrode: $\mathrm{Ag} \mid \mathrm{AgCl}, \mathrm{Cl}^{-}\left(0.1 \mathrm{~mol} \mathrm{~L}^{-1}\right)$.

Table 2. SWV and DPV reduction potentials of MBHA classes I, II, III and IV in aprotic medium DMF + TBAP $\left(0.1 \mathrm{~mol} \mathrm{~L}^{-1}\right), v=100 \mathrm{mV} \mathrm{s}^{-1}$. Working electrode: glassy carbon electrode (GCE) (Metrohm, $3 \mathrm{~mm}$ ); auxiliary electrode: platinum wire; reference electrode: $\mathrm{Ag} \mid \mathrm{AgCl}, \mathrm{Cl}^{-}$

\begin{tabular}{|c|c|c|c|c|c|c|c|}
\hline \multicolumn{4}{|c|}{ SWV } & \multicolumn{4}{|c|}{ DPV } \\
\hline AMBH & $\mathrm{Epc}_{1} / \mathrm{V}$ & AMBH & $\mathrm{Epc}_{1} / \mathrm{V}$ & AMBH & $\mathrm{Epc}_{1} / \mathrm{V}$ & AMBH & $\mathrm{Epc}_{1} / \mathrm{V}$ \\
\hline Ia & -0.914 & IIIa & -0.976 & Ia & -0.889 & IIIa & -0.951 \\
\hline $\mathrm{Ib}$ & -0.986 & IIIb & -1.032 & $\mathrm{Ib}$ & -0.965 & $\mathrm{IIIb}$ & -1.009 \\
\hline Ic & -0.999 & IIIc & -1.040 & Ic & -0.970 & IIIc & -0.988 \\
\hline IIa & -1.017 & IVa & -0.979 & IIa & -0.985 & IVa & -0.981 \\
\hline $\mathrm{IIb}$ & -1.026 & $\mathrm{IVb}$ & -1.021 & IIb & -1.003 & $\mathrm{IVb}$ & -0.990 \\
\hline IIc & a & IVc & -1.027 & IIc & a & IVc & -0.998 \\
\hline
\end{tabular}

anot present. 


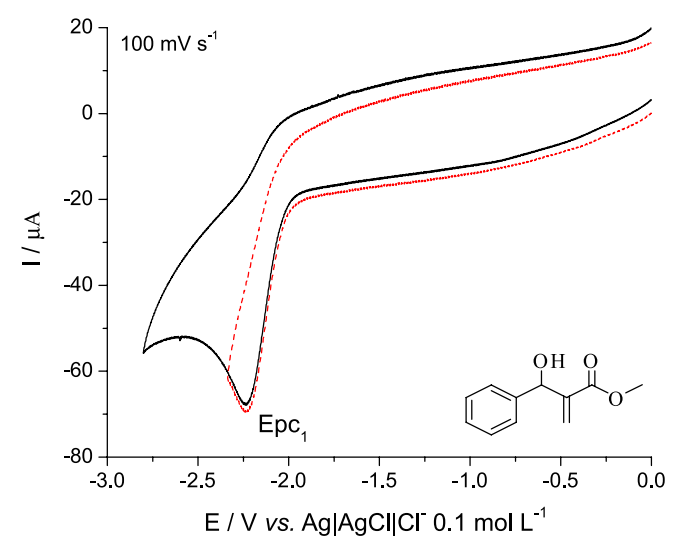

Figure 9. Cyclic voltammograms of methyl 2-phenylhydroxymethyl acrylate $\left(\mathrm{c}=1 \mathrm{mmol} \mathrm{L}^{-1}\right)$ in aprotic media (DMF + TBAP $\left.0.1 \mathrm{~mol} \mathrm{~L}^{-1}\right)$, $v=100 \mathrm{mV} \mathrm{s}^{-1}$. Working electrode: GCE (Metrohm, $3 \mathrm{~mm}$ diameter); counter electrode: platinum coil; reference electrode: $\mathrm{Ag} \mid \mathrm{AgCl}, \mathrm{Cl}^{-}\left(0.1 \mathrm{~mol} \mathrm{~L}^{-1}\right)$.

materials. Conformational effects are also very important in this type of analysis and were performed (Figure 10), indicating that an internal hydrogen bonding is formed in compounds Ia and IVa, which might be intensified in the anion-radical intermediates by allowing a better resonance stabilization. Hydrogen bonding was also observed on the side chain of acrylate derivatives, a feature that does not influence nitro reduction potential.

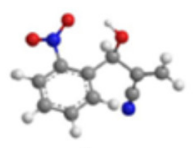

Ia

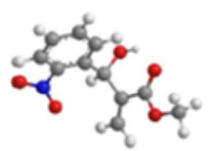

IIa

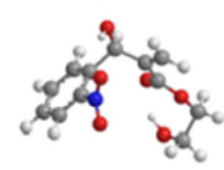

IIIa

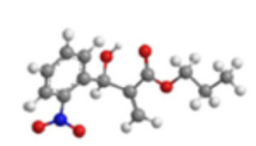

$\mathrm{IVa}$

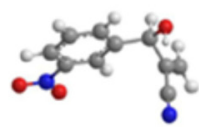

$\mathrm{Ib}$

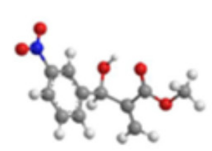

IIb

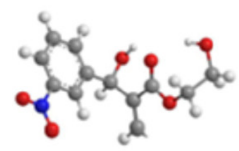

$\mathrm{IIIb}$

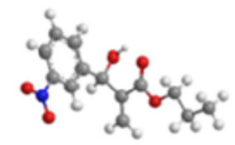

$\mathrm{IVb}$
Ic

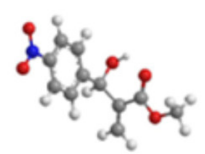

IIc

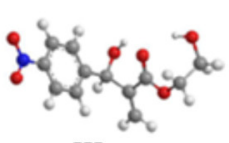

IIIc

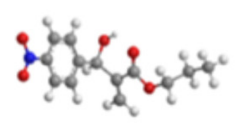

IVc

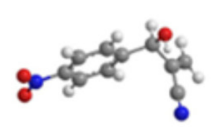

Figure 10. Conformational minima of MBHA Ia-IVc calculated from $\mathrm{HF} / 6-31+\mathrm{G}(\mathrm{d}) / \mathrm{PCM}$ on DMF simulations (see geometrical parameters for the conformational minima of MBHA Ia-IVc, in the SI section).

Analyses of HOMO and LUMO frontier orbitals were also performed (Table 3). It was not found a clear relationship between LUMO energies and the reduction potentials (see $\mathrm{Epc}_{1}$, Table 1) of the nitro group attached to the aromatic ring
Table 3. Calculated frontier orbitals, molecular hardness and charge of MBHA nitrogen atoms

\begin{tabular}{lcccc}
\hline MBHA & HOMO / eV & LUMO / eV & $N^{\mathrm{a}}$ & $\mathrm{Q}_{\mathrm{N}}{ }^{\mathrm{b}}$ \\
\hline Ia & -0.36546 & +0.04060 & -0.162430 & +0.219 \\
Ib & -0.36309 & +0.03556 & -0.163765 & +0.123 \\
Ic & -0.36622 & +0.03495 & -0.165635 & +0.114 \\
IIa & -0.35704 & +0.04747 & -0.154785 & +0.112 \\
IIb & -0.35713 & +0.03776 & -0.159685 & +0.091 \\
IIc & -0.36295 & +0.03774 & -0.162605 & +0.105 \\
IIIa & -0.36218 & +0.04327 & -0.159455 & +0.288 \\
IIIb & -0.35741 & +0.03703 & -0.160190 & +0.130 \\
IIIc & -0.36322 & +0.03754 & -0.16284 & +0.103 \\
IVa & -0.35681 & +0.04742 & -0.154695 & $+0.106^{\mathrm{c}}$ \\
IVb & -0.35674 & +0.03744 & -0.159650 & +0.124 \\
IVc & -0.36275 & +0.03783 & -0.162460 & +0.104 \\
\hline
\end{tabular}

${ }^{\mathrm{a}} \mathrm{N}=$ molecular hardness; ${ }^{\mathrm{b}} \mathrm{Q}_{\mathrm{N}}=$ Mulliken charges of nitrogen atoms of $\mathrm{NO}_{2}$ groups; 'an exception.

of MBHA. However, according to Paula and co-workers, ${ }^{17}$ when HOMO and LUMO values were used to calculate the molecular hardness, a more relevant parameter regarding to molecular reactivity, ${ }^{17}$ these correlations could be noted. The hardness can be used to evaluate the resistance of the electron to be dispersed on molecules, which will lead to modifications of the chemical reactivity and/or the interaction with an enzyme (or other biological target). The calculated values of molecular hardness $(N)$ showed in Table 3 revealed that the ortho-substituent in the same class of compounds (I, II, III or IV) are softer than their congeners MBHA. It is possible that the lower values of $N$ indicate that adducts may stabilize more efficiently the radical anion, facilitating their formation. It is worth noting that there is a good relationship between the values of $\mathrm{Epc}_{1}$ (Table 1), with the calculated values of hardness (Table 3 ) to their isomeric compounds, and the corresponding $\mathrm{IC}_{50}$ values presented in our previous work. ${ }^{15}$

Table 4 lists the main electrochemical parameters and data on leishmanicidal activity.

This evaluation is in accordance with values obtained from electrochemical $\left(\mathrm{Epc}_{1}\right)$ parameters and bioactivities. Moreover, the calculated charges for nitrogen atoms on $-\mathrm{NO}_{2}\left(\mathrm{Q}_{\mathrm{N}}\right.$, Table 3) indicated that in most cases, the most bioactive compounds carried more positive nitrogen charge, indicating a facilitated acceptance of electrons (higher electron affinity). In fact, it becomes evident that the intramolecular hydrogen bonding formation between $\mathrm{NO}_{2} \cdots \mathrm{HO}$ has an important role in molecular dispersion (softness) and the largest atomic charge on the nitrogen atom and both of these effects increasing the molecular bioactivity. Finally, a strong relationship between $\mathrm{IC}_{50}$ and 
Table 4. Comparison between the $50 \%$ inhibitory concentration $\left(\mathrm{IC}_{50}\right)$ against Leishmania amazonensis and the nitro reduction potential $\left(\right.$ Epc $\left._{1}\right)$ in aprotic medium (DMF + TBAP $0.1 \mathrm{~mol} \mathrm{~L}^{-1}$ ), obtained by CV

\begin{tabular}{|c|c|c|c|c|c|}
\hline MBHA & $\mathrm{IC}_{50} / \mu \mathrm{M}$ & $\mathrm{Epc}_{1} / \mathrm{V} v s . \mathrm{Ag} \mid \mathrm{AgCl}, \mathrm{Cl}^{-}\left(0.1 \mathrm{~mol} \mathrm{~L}^{-1}\right)$ & MBHA & $\mathrm{IC}_{50} / \mu \mathrm{M}$ & $\mathrm{Epc}_{1} / \mathrm{V} v s . \mathrm{Ag} \mid \mathrm{AgCl}, \mathrm{Cl}^{-}\left(0.1 \mathrm{~mol} \mathrm{~L}^{-1}\right)$ \\
\hline Ia & 62.00 & -0.944 & IIIa & 20.52 & -1.014 \\
\hline $\mathrm{Ib}$ & 238.27 & -1.028 & IIIb & 64.57 & -1.077 \\
\hline Ic & 128.27 & -1.029 & IIIc & 53.03 & -1.056 \\
\hline IIa & 50.08 & -1.061 & IVa & 28.38 & -1.009 \\
\hline $\mathrm{IIb}$ & 451.58 & -1.062 & $\mathrm{IVb}$ & 72.23 & -1.063 \\
\hline IIc & 196.16 & -1.084 & IVc & 52.04 & -1.058 \\
\hline
\end{tabular}

Epc $_{1}$ values was observed (Table 4) when comparing the inter-series of MBHA compounds. For instance, MBHA Ia presented higher leishmanicidal activity (lower $\mathrm{IC}_{50}$ ) than $\mathrm{Ib}$ and Ic MBHA congeners and at the same time had the least negative $\mathrm{Epc}_{1}$ (higher electron affinity). This tendency is recurrent throughout all Table 4 .

This conclusion, however, has to be cautiously considered as the bioactivity does not depend solely on the ease of reduction of the nitro group but upon the mechanism of action involving the global molecular structure of the substrates.

\section{Conclusions}

The $\alpha, \beta$-unsaturated ester and nitrile moieties seem to be crucial in the mechanism of action of these compounds, especially in regards to biological nucleophilic targets of Leishmania. The presence of a 7-membered ring intramolecular hydrogen bond (IHB) in the MBHA ortho-substituted seems to be a structural requirement for the remarkable bioactivities of these adducts in comparison to their respective isomers. Finally, a strong correlation was obtained between $\mathrm{Epc}_{1}$ and $\mathrm{IC}_{50}$ values when compared to their isomeric compounds. The most stable conformers in in silico solvated environment of all MBHA were obtained and frontier orbitals were calculated. Softer compounds (lower molecular hardness, $N$ ) were the most bioactive against Leishmania amazonensis.

\section{Supplementary Information}

The spectroscopic data and geometrical parameters for the conformational minima of MBHA Ia-IVc are available free of charge at http://jbcs.sbq.org.br as a PDF file.

\section{Acknowledgments}

The authors are grateful to Cleylton Bezerra Lopes and Waldomiro Pinho Júnior for technical assistance and to Conselho Nacional de Desenvolvimento Científico e Tecnológico (CNPq), Coordenação de Aperfeiçoamento de Pessoal de Nível Superior (CAPES), Fundação de Apoio à Pesquisa do Estado da Paraíba (FAPESQ-PB) and Fundação de Amparo à Pesquisa do Estado de Alagoas (FAPEAL) and Instituto Nacional de Ciência e Tecnologia (INCT-Bioanalítica) for financial support.

\section{References}

1. Morita, K.; Suzuki, Z.; Hirose, H.; Bull. Chem. Soc. Jpn. 1968, 41, 2815; Baylis, A. B.; Hillman, M. E. D.; German Patent 2,155,113 1972 (CA 77: 34174q).

2. For reviews, see: Basavaiah, D.; Reddy, B. S.; Badsara, S. S.; Chem. Rev. 2010, 110, 5447; Basavaiah, D.; Rao, K. V.; Reddy, R. J.; Chem. Soc. Rev. 2007, 36, 1581; Masson, G.; Housseman, C.; Zhu, J.; Angew. Chem., Int. Ed. 2007, 46, 4614; Basavaiah, D.; Rao, J. A.; Satyanarayana, T.; Chem. Rev. 2003, 103, 811; Langer, P.; Angew. Chem., Int. Ed. 2000, 39, 3049; Coelho, F. A. S.; Almeida, W. P.; Quím. Nova 2000, 23, 98; Basavaiah, D.; Rao, P. D.; Hyma, R. S.; Tetrahedron 1996, 52, 8001; Drewes, S. E.; Roos, G. H. P.; Tetrahedron 1988, 44, 4653.

3. Kundu, M. K.; Sundar, N.; Kumar, S. K.; Bhat, S.; Biswas, S.; Valecha, N.; Bioorg. Med. Chem. 1999, 9, 731.

4. Vasconcellos, M. L. A. A.; Silva, T. M. S.; Camara, C. A.; Martins, R. M.; Lacerda, K. M.; Lopes, H. M.; Pereira, V. L. P.; de Souza, R. O. M. A.; Crespo, L. T. C.; Pest Manage. Sci. 2006, 62, 288.

5. Narender, P.; Gangadasu, B.; Biswas, S.; Rao, J.; Bioorg. Med. Chem. 2005, 15, 5378; Narender, P.; Srinivas, U.; Ravinder, M.; Rao, B.; Ramesh, C.; Harakishore, K.; Gangadasu, B.; Murthy, U. S. N.; Rao, V. J.; Bioorg. Med. Chem. 2006, 14, 4600; Souza, R. O. M. A.; Pereira, V. L. P.; Muzitano, M. F.; Falcão, C. A. B.; Rossi-Bergmann, B.; Filho, E. B. A.; Vasconcellos, M. L. A. A.; Eur. J. Med. Chem. 2007, 42, 99; Barbosa, T. P.; Lima Jr., C. G.; Silva, F. P. L.; Lopes, H. M.; Figueiredo, L. R. F.; Sousa, S. C. O.; Batista, G. N.; Silva, T. G.; Silva T. M. S.; Oliveira, M. R.; Vasconcellos, M. L. A. A.; Eur. J. Med. Chem. 2009, 44, 1726; Junior, C. G. L.; Assis, P. A. C.; Silva, F. P. L.; Sousa, S. C. O.; 
Andrade, N. G.; Barbosa, T. P.; Néris, P. L. N.; Segundo, L. V. G.; Anjos, I. C.; Carvalho, G. A. U.; Rocha, G. B.; Oliveira, M. R.; Vasconcellos, M. L. A. A.; Bioorg. Chem. 2010, 38, 279; Sandes, J. M.; Borges, A. R.; Junior, C. G. L.; Silva, F. P. L.; Carvalho, G. A. U.; Rocha, G. B.; Vasconcellos, M. L. A. A.; Figueiredo, R. B. Q.; Bioorg. Chem. 2010, 38, 190; Barbosa, T. P.; Sousa, S. C. O.; Amorim, F. M.; Rodrigues, Y. K. S.; de Assis, P. A. C.; Caldas, J. P. A.; Oliveira, M. R.; Vasconcellos, M. L. A. A.; Bioorg. Med. Chem. 2011, 19, 4250.

6. Rajan, Y. C.; Kanakam, C. C.; Selvam, S. P.; Murugesan, K.; Tetrahedron Lett. 2007, 48, 8562.

7. Mohan, R.; Rastogi, N.; Namboothiri, I. N. N.; Mobin, S. M. M.; Panda, D.; Bioorg. Med. Chem. 2006, 14, 8073.

8. Kohn, L. K.; Pavam, C. H.; Veronese, D.; Coelho, F.; Carvalho, J. E.; Almeida,W. P.; Eur. J. Med. Chem. 2006, 41, 738.

9. Goulart, M. O. F.; Souza, A. A.; De Abreu, F. C.; De Paula, F. S.; Almeida, W. P.; Buriez, O.; Amatore, C.; J. Electrochem. Soc. 2007, 154, 121; Duarte, C. D.; Tributino, J. L. M.; Lacerda, D. I.; Martins, M. V.; Alexandre-Moreira, M. S.; Dutra, F.; Bechara, E. J. H.; De-Paula, F. S.; Goulart, M. O. F.; Ferreira, J. ; Calixto, J. B.; Nunes, M. P. ; Bertho, A. L. ; Miranda, A. L. P.; Barreiro, E. J.; Fraga, C. A. M.; Bioorg. Med. Chem. 2007, 15, 2421.

10. Squella, J. A.; Bollo, S.; Núñez-Vergara, L. J.; Curr. Org. Chem. 2005, 9, 565; de Abreu, F. C.; Ferraz, P. A. M.; Goulart, M. O. F.; J. Braz. Chem. Soc. 2002, 13, 19.

11. Goulart, M. O.F.; Zani, C.L.; Tonholo, J.; Freitas, L. R.; de Abreu, F. C.; Oliveira, A. B.; Raslan, D. S.; Starling, S.; Chiari, E.; Bioorg. Med. Chem. Let. 1997, 7, 2043.

12. Bhattacharjee, A. K.; Skanchy, D. J.; Jennings, B.; Hudson, T. H.; Brendle, J.; Werbovetz, K. A.; Bioorg. Med. Chem. 2002, 10, 1979; Delfín, D. A.; Morgan, R. E.; Zhu, X.; Werbovetz, K. A.; Bioorg. Med. Chem. 2009, 17, 820.

13. Frézard, F.; Demicheli, C.; Ribeiro, R. R.; Molecules 2009, 14, 2317.

14. Alencar, F. E. B.; Ventura, E.; do Monte, S. A.; Oliveira, B. G.; Junior, C. G. L.; Rocha, G. B.; Vasconcellos, M. L. A. A.; Chem. Phys. Lett. 2007, 499, 336.
15. Silva, F. P. L.; de Assis, P. A.C.; Lima Jr., C. G.; de Andrade, N. G.; da Cunha, S. M. D.; Oliveira, M. R.; Vasconcellos, M. L. A. A.; Eur. J. Med. Chem. 2011, 46, 4295; Lima-Junior, C. G.; Silva F. P. L.; de Oliveira R. G.; Subrinho F. L.; Vasconcellos, M. L. A. A.; J. Braz. Chem Soc. 2011, 22, 2220.

16. Gaussian 09, Revision A.1, Frisch, M. J.; Trucks, G. W.; Schlegel, H. B.; Scuseria, G. E.; Robb, M. A.; Cheeseman, J. R.; Scalmani, G.; Barone, V.; Mennucci, B.; Petersson, G. A.; Nakatsuji, H.; Caricato, M.; Li, X.; Hratchian, H. P.; Izmaylov, A. F.; Bloino, J.; Zheng, G.; Sonnenberg, J. L.; Hada, M.; Ehara, M.; Toyota, K.; Fukuda, R.; Hasegawa, J.; Ishida, M.; Nakajima, T.; Honda, Y.; Kitao, O.; Nakai, H.; Vreven, T.; Montgomery, Jr., J. A.; Peralta, J. E.; Ogliaro, F.; Bearpark, M.; Heyd, J. J.; Brothers, E.; Kudin, K. N.; Staroverov, V. N.; Kobayashi, R.; Normand, J.; Raghavachari, K.; Rendell, A.; Burant, J. C.; Iyengar, S. S.; Tomasi, J.; Cossi, M.; Rega, N.; Millam, N. J.; Klene, M.; Knox, J. E.; Cross, J. B.; Bakken, V.; Adamo, C.; Jaramillo, J.; Gomperts, R.; Stratmann, R. E.; Yazyev, O.; Austin, A. J.; Cammi, R.; Pomelli, C.; Ochterski, J. W.; Martin, R. L.; Morokuma, K.; Zakrzewski, V. G.; Voth, G. A.; Salvador, P.; Dannenberg, J. J.; Dapprich, S.; Daniels, A. D.; Farkas, Ö.; Foresman, J. B.; Ortiz, J. V.; Cioslowski, J.; Fox, D. J.; Gaussian, Inc., Wallingford CT, 2009.

17. Paula, F. R.; Trossini, G. H. G.; Ferreira. E. I.; Serrano, S. H. P.; Menezes, C. M. S.; Tavares, L. C.; J. Braz. Chem. Soc. 2010, 21,740 .

18. Cavalcanti, J. C. M.; Oliveira, N. V.; De Moura, M. A. B. F.; Fruttero, R.; Bertinaria, M.; Goulart, M. O. F.; J. Electroanal. Chem. 2004, 571, 177.

19. de Azevedo, D. C.; Boodts, J. F. C.; Cavalcanti, J. C. M.; Santana, A. E. G.; dos Santos, A. F.; Bento, E. S.; Tonholo, J; Goulart, M. O. F.; J. Electroanal. Chem. 1999, 466, 99.

20. de Paula, F. S; Sales, E. M.; Vallaro, M.; Fruttero, R.; Goulart, M. O. F.; J. Electroanal. Chem. 2005, 579, 33.

Submitted: January 26, 2012 Published online: April 17, 2012 